Наталья Корниенко

Институт мировой литературы им. А. М. Горького РАН

natalkornienko@yandex.ru

Nataliya Kornienko

A. M. Gorky Institute of World Literature Russian Academy of Sciences natalkornienko@yandex.ru

\title{
«СОЦИАЛЬНЫЙ РОМАН» АНДРЕЯ ПЛАТОНОВА: КОНТЕКСТЫ ТВОРЧЕСТВА И ЭПОХИ
}

\author{
«SOCIAL NOVEL» BY ANDREY PLATONOV: \\ CONTEXTS OF CREATIVITY AND EPOCH
}

Статья посвящена проблематике романного искусства Андрея Платонова в контекстах творчества писателя и литературной эпохи 1920-1930-х гг., когда роман становится ведущим прозаическим жанром в творчестве прозаиков как советской России, так и эмиграции. Анализируется история создания главного романа писателя - романа Чевенгур (1927-1929), а также история недописанных (Технический роман, Счастливая Москва) и ненаписанных романов (роман с условным названием Стратилат и Путешествие из Ленинграда в Москву).

Ключевые слова: Платонов, революция, контексты, биография, роман, редакции романа, письма, записные книжки.

The paper focuses on Platonov's novel in the context of the writer's work and the literary era of the 1920s-1930s, when it became a leading prose genre in the works of prose writers of both Soviet Russia and emigration. The author analyzes the history of the creation of the main novel of the writer - the novel Chevengur (1927-1929), as well as the history of unfinished (Technical Novel, Happy Moscow) and unwritten novels (the novel with the conditional title Stratilat and Journey from Leningrad to Moscow).

Keywords: Platonov, revolution, contexts, biography, novel, novel editions, letters, notebooks.

...одни честные натужения на действительно социальный роман (диалектика событий)...

А. Платонов. «Фабрика литературы» (1926)

Мое молодое, серьезное (смешное по форме) - остается главным по содержанию навсегда, надолго.

А. Платонов. Записная книжка (1932)

Предлагаемая статья является обобщением многолетней текстологической работы по подготовке первых публикаций рукописного наследия и научного Собрания сочинений А. П. Платонова. 
О главном романе писателя - это, конечно, Чевенгур (1927-1929) мы сегодня знаем значительно больше, чем еще десять лет назад. Реконструированы и описаны история автографа, который оказался разорванным между двумя городами (Москвой и Ленинградом) $)^{1}$, а также история сводной рукописи романа, составленной Платоновым из рукописных и машинописных страниц (Архив А. П. Платонова 2019). Практически полностью (за исключением пяти страниц) восстановлена первая редакция романа (Строители страны) (Платонов 2021: 348-541), описана история текста и творческая история романа, составлен реальный комментарий (Платонов 2021: 545-705). Исследователи получили своды нового, ранее неизвестного архивного материала для изучения одного из самых загадочных русских романов XX в.

С переходом семейного архива писателя на государственное хранение (в ИМЛИ РАН) исследователям стали доступны оригиналы писем Платонова к невесте и жене Марии Кашинцевой ${ }^{2}$, являющиеся важнейшим источником для изучения истории текста неоконченной повести «Однажды любившие», первой редакции романа Чевенгур, рассказов о любви 1936 г. ${ }^{3}$.

О втором романе (с условным названием Стратилат), над которым Платонов работал в начале 1930-х гг., мы знаем только из записных книжек писателя (Платонов 2000: 68-80, 94-110). Материал записных книжек 19311932 гг. представляет богатейший и по-своему уникальный материал для изучения рефлексии писателя над темой, сюжетом, системой героев и главной идеей романа. Текст романа не сохранился.

История третьего романа (Технический роман, 1932-1933) имеет почти детективную историю. В 1933 г. машинопись первой части романа оказалась в секретно-политическом отделе ОГПУ 4 , где с нее была подготовлена методом монтажа новая машинопись, включившая политически крамольные фрагменты текста и вставки, представляющие краткий пересказ основной фабулы романа. Эта машинопись была положена в папку с надписью: «Неизданные произведения (изъятые при обыске) Андрея Платонова», хранящейся в Центральном архиве ФСБ. Именно по этому источнику Технический роман впервые был опубликован в 1991 г. (Платонов 1991). Красивое метафорическое представление романа в предисловии В. Шенталинского «Арестованное слово» - «строение с неубранными лесами, но и масштаб, и архитектура, и качество налицо» - сопровождалось концептуальным обоснованием новаторской монтажной формы. В качестве одного из источников текста романа назван ранний рассказ «Родина электричества»: «Зерно, из которого разрастается “Технический роман”, - ранний рассказ “Родина

1 Впервые об истории автографа романа см. (Вьюгин 1995, Корниенко 2005).

2 Впервые все сохранившиеся письма Платонова к жене опубл.: А. П. Платонов М. А. Платоновой. 1921-1945 гг. (Архив А. П. Платонова 2009: 432-577).

3 Подробно об этом см. (Корниенко 2009: 377-397; Корниенко 2013: 7-70).

4 ОГПУ - Объединенное государственное политическое управление, специальный орган государственной безопасности СССР. 
электричества" (1926). Около трех страниц из пятидесяти почти совпадают - это вообще характерно для Платонова: вариативность темы, отпочкование сюжетных веток, клеточное деление образов, неопределенность исхода» (Платонов 1991: 3). Изданный огромным тиражом (90 000 экземпляров!) данный текст Технического романа и до сегодняшнего дня встречается в переизданиях Платонова, как и предложенная публикатором история текста романа. Так в первом популярном Собрании сочинений Платонова в комментарии к повести «Хлеб и чтение» можно прочитать: «Текст повести перекликается с написанным в то же время рассказом "Родина электричества" и “Техническим романом". В двух последних встречаются сцены, целиком совпадающие с текстом повести. По всей вероятности, для написания всех трех произведений Платонов воспользовался материалом, имеющимся у него в архиве» (Платонов 2009: 556). Это написано в 2009 г. Скажем сразу, что никаких трех самостоятельных произведений нет, а речь идет об одном источнике. К этому времени в малотиражном научном издании «Страна философов» Андрея Платонова: проблемы творчества (тираж - 1000 экз.) были впервые представлены полный текст Технического романа, а также реальная, а не придуманная история текста нового романа (Платонов 2000). Находящийся в папке архива ФСБ «Неизданные произведения (изъятые при обыске) Андрея Платонова» текст Технического романа был умело смонтирован сотрудниками ОГПУ, которыми и были написаны вставки, заменившие страницы сокращенного текста. В архиве ФСБ находится фотокопия оригинальной машинописи Технического романа, с которой работали сотрудники ОГПУ, оставив в ней свои пометы. Представленная нам для работы фотокопия позволила разгадать природу сделанных в ней помет и описать историю текста, помещенного в папку «Неизданные произведения...» (Корниенко 2000: 741-742).

Тогда же в семейном архиве Платонова (сегодня фонд А. П. Платонова в Отделе рукописей ИМЛИ) была выявлена неполная машинопись текста, идентичная машинописи в архиве ФСБ, но с другим названием «Хлеб и чтение». В машинописи отсутствовали страницы, посвященные поездке Душина летом 1920 г. в деревню Верчовку. Эти страницы были использованы Платоновым при написании рассказа «Родина электричества» (впервые опубликован в 1939 г. в журнале Индустрия социализма; составная рукопись рассказа с машинописными страницами из Технического романа находится в фонде Платонова ОР ИМЛИ). Машинопись семейного архива имеет еще одну примету: первая глава Технического романа («Хлеб и чтение») превращена в заглавие всего текста с новым жанровым обозначением «Повесть», а на последней странице зачеркнуто «Конец 1-й главы» и вписано «Конец». Но это исправление, как и подготовка на основе одной главы Texнического романа рассказа «Родина электричества», более позднего времени, когда Платонов примет решение не продолжать работу над романом.

Итак, к 1933 г. была написана первая часть Технического романа, которая заканчивалась кульминационной сценой выступления главного героя 
инженера Душина с главным собственным сочинением «о применении электричества для социализма» (Платонов 2009: 503) и пришедшей из Москвы вестью об историческом плане электрификации всей страны (ГОЭЛPO). Эта глубоко личная для Платонова тема (в 1921 г. выходит первая его небольшая книжка Электрификация, в 1923-1924 гг. он занимается вопросами электрификации Воронежской губернии). В 1931 г. отмечается 10-летие принятия грандиозного плана, на Первой Всесоюзной конференции работников социалистической промышленности И. Сталин сформулировал один из главных лозунгов десятилетия «Техника в период реконструкции решает всё» (Сталин: 41), а одним из важнейших событий 1932 г. становится обсуждение плана второй пятилетки и важнейшей его части - второго плана электрификации всей страны. Обсуждению этого плана посвящена большая Всесоюзная конференция (май 1932), материалы которой печатаются во всех центральных газетах: «“Коммунизм есть советская власть плюс электрификация всей страны”, - сказал тов. Ленин, и в этих словах весь смысл, вся сущность настоящей конференции» (Известия 8.05.1932: 2); «Успешное завершение в первой пятилетке ленинского плана Гоэлро является непосредственной предпосылкой плана электрификации второй пятилетки, плана создания энергетической базы, которая по директиве XVII конференции ВКП(б) должен обеспечить стране в 1937 г. не менее 100 миллиардов киловатт-часов электроэнергии против 17 миллиардов в 1932 г.» (Правда 21.05.1932: 2) и др.

Листая центральные газеты этого времени, можно обнаружить самые разные переклички с текстом Технического романа. Так, даже к знаменитым стихам председателя сельсовета Верчовки про голод, засуху 1920 г. и покорение природы, например, к этим строкам: «Стоит как башня наша власть науки и этот вавилон из ящериц, засухи разрушен будет умною рукой. Не мы создали этот мир несчастный, но мы его устроим до конца. $<\ldots>$ Не дремлет разум коммуниста, и рук ему никто не отобьет. Напротив - он всю землю чисто в научное давление возьмет...» (Платонов 2009: 459) - можно найти документальный прообраз на страницах сообщений о втором плане электрификации страны. Вот как описывалась одна из важнейших задач второй пятилетки — «большевистское разрешение вопроса о борьбе с засухой»: «В 1931 г. несколько миллионов посевных площадей повреждено засухой. <..> Стихийные силы природы не могут внести растерянность в социалистические ряды, не могут отбросить назад наше хозяйство, ибо социалистическое хозяйство развивается на основе крупной промышленности и электрификации. <...> И большевики вступают в бой с климатом, переходят от обороны к наступлению на засуху» (Известия 24.05.1932: 1).

В июле 1933 г. Платонов подписал соглашение с ГИХЛом (Государственное издательство «Художественная литература») на издание Технического романа - размером 15 печатных листов. Роман включался в проекты издательского плана на 1934 г., однако в окончательных планах издатель- 
ства 1934, а затем и 1935 г. появляется уже другой роман Счастливая Москва $a^{5}$. Как свидетельствует письмо Платонова в ГИХЛ от 6 декабря 1933 г. ${ }^{6}$, в 1933 г. на рабочем столе Платонова находились оба романа.

Отложив в сторону Технический роман, Платонов в 1933 г. приступает к написанию романа Счастливая Москва. Он планирует завершить роман к январю 1934 г. Важнейшим источником для изучения творческой лаборатории третьего романа являются записные книжки 1933-1934 гг. Работа над романом Счастливая Москва была приостановлена весной 1934 г.: с марта Платонов переключается на работу над азиатским циклом произведений, это: рассказ «Такыр», повести «Македонский офицер» (не окончена), «Джан», статьи. Записные книжки свидетельствуют, что, даже находясь в Туркмении (весной 1934 и зимой 1935 г.), Платонов напряженно размыщляет о судьбе главной героини романа Счастливая Москва, однако, кажется, к рукописи романа он больше не возвращался. При этом вплоть до 1937 г. роман значился в планах издательств. В 1934 г. на основе написанных глав романа подготовлены два текста: рассказы «Любовь к дальнему» и «Московская скрипка». Первые шесть глав романа тогда же были переведены в машинопись (находится в фонде Платонова РГАЛИ). Именно этим источником исследователи располагали многие годы в своих суждениях о неоконченном романе. Автор статьи, опираясь на материал этих 6 глав романа, тоже выстроил, как ему казалось, убедительную гипотезу:

«Роман создавался как своеобразная альтернатива характеру умствующего герой произведений 20 -х годов - повестей и романа “Чевенгур”: образ главной героини - девушки Москвы, сироты, обретающей свой путь в фантастической по своим деяниям современности, задавался в открытости всем ветрам природы и истории. Главы оставшегося незаконченным романа свидетельствуют о мощном сопротивлении романной поэтики Платонова новому типу героя. Роман фактически как бы разобьется на разные идейнотематические центры, художественные решения которых Платонов даст в рассказах второй половины 30-х годов» (Корниенко 1990: 182).

Когда текст со статьей вышел в свет, я уже занималась подготовкой к первой публикации полного текста романа Счастливая Москва (опубликован в 1991 г. в журнале Новый мир, №9). Как таковой единой рукописи романа в семейном архиве не было. Текст романа составлялся из рукописных страниц, оказавшихся в разных папках. В рукописи нет не только привычной для последних страниц рукописей Платонова записи «Конец», но и не проведена авторская редподготовка текста: остались не выбранные варианты слов и предложений, незавершенные фразы и т. п. Вопрос о за-

5 РГАЛИ. Ф. 613 (ГИХЛ). Оп. 1. Ед. хр. 21. Л. 31, 46, 143, 204.

6 В письме в сектор современной художественной литературы ГИХЛ Платонов сообщал, что рукопись романа Счастливая Москва будет представлена в январе 1934 г., что ее задержка связана с болезнью и с тем «обстоятельством», что «по одному договору пишу не один роман, а два (“Сч. Москва” — второй, первый — “Техн. Роман”)» (ОР ИМЛИ. Ф. 7. Оп. 3. Ед. хр. 41). 
вершенности работы Платонова над текстом остается открытым. При этом очевидна эпическая завершенность текста, однако, это характерная примета вообще больших эпических форм Платонова - повести и романа, в которых каждая глава, как в циклах народных эпических жанров, обладает завершенностью.

В 1937 г. вместо романа выходит книга рассказов Река Потудань, в планах издательства появляется заявка на новый роман Путешествие из Ленинграда в Москву в 1937 году. В феврале 1937 г., в дни Пушкинского пленума Союза писателей СССР (в 1937 г. широко отмечалось 100-летие смерти А. С. Пушкина) писатель совершает поездку по маршруту Радищева из Ленинграда в Москву. От этой поездки осталась карта поездки Радищева с пометами Платонова, а также записная книжка, с радищевскими (Путешествие из Петербурга в Москву, 1790) и пушкинскими (неоконченная повесть «Путешествие из Москвы в Петербург», 1833-1835) сюжетами о встречах писателя в этой поездке, портретами детей и стариков, размышлениями об увиденном и т. д. (Платонов 2000: 191-208). Кроме записной книжки сохранились наброски «Предисловий» к роману, а также страница с эпиграфом из Радищева («Я взглянул окрест...»), вложенная в папку с первыми страницами романа. В качестве первых страниц нового романа взяты страницы из рукописи романа Счастливая Москва. Эта страница, где зачеркнуто название Счастливая Москва, а вместо него вписано «Путешествие из Л. в М.» и сделана помета «2 эпиграфа из Радищева», воспроизводится на обложках нашего издания «Страна философов» Андрея Платонова. Вплоть до 1941 г. роман Путешествие из Ленинграда в Москву в 1937 г. значился в планах писателя и издательств. Был ли роман написан/дописан остается неизвестным, существует легенда, что чемоданчик с рукописью романа был похищен у писателя в дороге в Уфу в 1941 г.

Такова краткая источниковедческая справка к заявленной теме статьи. Bсе дошедшие до нас тексты романов Платонова отличают автобиографизм, острая социальность сюжета и одновременная погруженность социального сюжета в философскую проблематику смысла истории, создания «нового мира» и нового человека. Рефлексия над этой проблематикой составляет основное содержание записных книжек, становится темой статей, посвященных собственно философским темам, которые выступают своеобразными авторским внетекстовым комментарием философских узлов романа. Этот статус для романа Чевенгур имеют статьи «О любви» и «Питомник нового человека» 1927 г., для Технического романа и Счастливой Москвы - философское эссе «О первой социалистической трагедии» (1934), для Путешествия из Ленинграда в Москву — статьи о Пушкине 1937 г.

Для всех романов Платонов планировал приблизительно один объем 15 а. л. Тексты написанных частей двух заявленных романов - Технического романа и Счастливой Москвы - составляют приблизительно 5 авторских листов, т. е., представляют первую треть плана. Осуществлен этот план только в отношении романа Чевенгур. 
Без преувеличения, именно революция 1917 г. сделала роман ведущим прозаическим жанром в русской литературе XX века и оставалась на десятилетия его главной темой. В 1920-1921 гг. (еще не окончилась Гражданская война!), выходят в свет первые русские романы о революции и Гражданской войне - все они вошли в золотой фонд русской классики: Хождение по мукам А. Толстого, Гольий год Б. Пильняка, Два мира В. Зазубрина, Хулио Хуренито И. Эренбурга, Револючия и фронт В. Шкловского. Романы предложили различные политические, исторические, философские и литературные контексты осмысления революции 1917 г. в русской и мировой истории и представили панораму жизни предреволюционной и революционной России, отодвинув экспозицию революционных событий сначала к Первой мировой войне, а затем - рубежу веков. «Новая литературная личность сострадательна с революцией, или соокаянна с ней, - писал А. Н. Толстой в 1922 г., резюмируя собственный опыт романного постижения революции и опыт своих современников. - На крови и бедствиях заложен фундамент, на котором строится новый храм трагедии. Фундамент трагедии - миф. Фундамент новой, русской трагедии - миф революции: ее роковая последовательность, ее противоречия, ее высоты и бездны, ее обольщения и непереносимый ужас, ее сложная, многоголосая, как фуга, сама себя уязвляющая, исступленно творческая, славянская душа. Ее неотделимое участие в совершающемся. <... > Они же, новые писатели, - дети полей войны. А на полях войны - нет прикрас: грязно, кроваво, честно и мужественно» (Толстой, 1922).

У каждого писателя была своя революция и собственный опыт ее переживания и осмысления. Автобиографизм - общая черта таких на первых взгляд разных (с точки зрения поэтики) романов как Гольй год и Два мира, Белая гвардия и Россия, кровью умытая, Чевенгур и Тихий Дон. Этот пафос литературной эпохи первого советского десятилетия замечательно передан в позднем признании К. Паустовского: «Литература двадцатых годов была литературой эгоцентрической - 90 \% литература занималась вопросом: как относится революция ко мне и как я отношусь к революции» 7 .

С окончанием Гражданской войны за роман «засели»8 практически все прозаики как советской России, так и русской эмиграции. Десятилетие революции отмечено новыми романами, каждый из которых представлял свой миф революции как главного события современной русской истории.

Платонов, в отличие от его современников, заявивших о себе, как и он, в революционные годы, после многообещаюегго яркого дебюта на стра-

7 Стенограмма обсуждения основных положений доклада К. Симонова на предстоящем 2-м съезде писателей. 20 сентября 1954 г. (РГАЛИ. Ф. 2464. Оп. 1. Ед. хр. 306. Л. 45).

8 См. письмо К. Федина М. Горькому от 28 августа 1922 г.: «Точно сговорившись, все мы засели за "романы". $<\ldots>$ я - роман о войне и революции. $<\ldots>$ Очевидно, одно и то же можно сказать по-разному. А раз так - как идти, чтобы не сорваться в пропасть?» $(\mathrm{Ce}$ рапионовы братья: 40-42) 
ницах воронежской и московской периодики 1918-1921 гг., совершает «уход из литературы»9 и только в 1927 г. — книгой Епифанские шлюзы, можно сказать, вступает во всесоюзную литературную жизнь.

О замысле первого романа - это роман о Пугачеве — мы знаем из его январских писем 1927 г. Тамбова, где он служит губернским мелиоратором: «Пугачева я буду писать долго и старательно, и мне нужно много материала к нему. Это роман, который я закончу к осени. <..> Я хочу работать в Пугачеве для себя, а не для рынка. Будь он проклят!» (Платонов 2013: 204). Как заметил Т. Лангерак, проанализировавший «историко-художественную прозу» Платонова 1926-1927 гг., «как и другие писатели его времени, Платонов искал в прошлом параллели с настоящим» (Лангерак 1995: 111). Однако от замысла романа о Пугачеве Платонов отказался. Трудно сказать о причинах этого решения. В 1925-1926 гг. отмечалось 150-летие казни Пугачева и материала о Пугачеве печаталось не мало. Платонов с ним знакомился и использовал его в рассказе «Иван Жох», своеобразном осколке от замысла романа.

В Тамбове Платонов в начале января 1927 г. завершает фантастическую повесть «Эфирный тракт», в феврале-марте пишет рассказ «Город Градов», превращая вскоре его в повесть. Вернувшись в Москву в марте 1927 г., он готовит первую книгу прозы к изданию, пишет сценарии, создает повесть «Сокровенный человек». Летом 1927 г. делает заявку на роман о революции. 3 июля 1927 г. в письме Марии Александровне в Крым, исполненном трагических признаний о жизни, творчестве и любви, Платонов сообщает: «Пишу о нашей любви. Это сверхъестественно тяжело. Я же просто отдираю корки с сердца и разглядываю его, чтобы записать, как оно мучается. Вообще, настоящий писатель это жертва и экспериментатор в одном лице. Но не нарочно это делается, а само собой так получается» (Платонов 2013: 228). 9 июля 1927 г. датируется запись на книге Епифанские шлюзы: «Марии, другу и любимой, - зреющей звезде моего разума, теплоте моего сердца» ${ }^{10}$. В письме жене (датируется 9-11 июля 1927 г.) мы находим сообщение о возможности подписать с издательством «Молодая гвардия» «договор на роман в 15 листов» (Платонов 2013: 232-233). Очевидно, в эти дни готовилась заявка на роман с условным названием Зреющая звез$\partial a$, в которой указывается: «Размер романа - 15 авторских листов. Четыре части: в каждой части по пять глав». В заявке описан «краткий план романа» об истории становления мальчика, а затем юноши из рабочей слободы; план включает: детство мальчика; религиозные и политические искания ранней юности, первую любовь героя; историю «трех друзей» в годы революции и Гражданской войны; первый послевоенный год учебы и творче-

9 С осени 1921 г. Платонов занимается вопросами борьбы с засухой, вскоре переходит на постоянную службу в Губернское земельное управление, где занимается вопросами мелиорации и электрификации, становится губернским мелиоратором (Антонова 2016: 357-474).

10 Книга с дарственной хранится в фонде Платонова Отдела рукописей ИМЛИ (OP ИМЛИ. Ф. 629. Оп. 5. Ед. хр. 6). 
ской работы, вновь настигшую героя любовь - «крутую, резкую, душную, граничащую с безумием»; большую инженерную работу, помогающую герою излечиться от любви; строительство новой страны, в описании которого появляется любимый Платоновым экскаватор.

Таков грандиозный сюжет романа, хронологические рамки которого охватывают период с 1906 г. до начала двадцатых годов. Платонов подчеркивает, что в представленном плане «не все понятно и последовательно», что в романе «все оправдывается», и заключает: «Вещи, о которых я буду писать, мне хорошо и опытно знакомы» (Платонов 2021: 345-347).

Заявленный план романа, в ходе его художественной реализации не раз существенно скорректированный, сохранит свою во многом автобиографическую основу, связанную с воронежским периодом жизни, творчества и философских исканий писателя, прежде всего - с 1919-1921 гг. Этими годами отмечены нашедшие отражение в романе важнейшие события и детали в жизни молодого Платонова: начало журналистской работы в местных изданиях; поездка в Новохоперск; учеба в железнодорожном политехникуме; тиф; круг чтения и друзей; голод; создание грандиозного проекта по борьбе с засухой и голодом («Земчека»); первая любовь, встреча с будущей женой Марией Кашинцевой и т. п. ${ }^{11}$ Это было время активных публикаций и высказываний рабочего-философа Платонова, кажется, по всем возможным вопросам истории, современности, культуры, философии, составившими книгу статей Думы коммуниста (1921; не была опубликована). Актуальность философско-эстетических исканий Платонова начала 1920-х гг. подтверждают его статьи 1927 г., возвращающие в поле современного научного знания и культуры основной вопрос философии - о мире (материи) и познаваемости мира, абсолютном и относительном знании, религиозной вере и научном знании, истине в идеализме и материализме и т. п. (неоконченная статья «О любви» и статья «Питомник нового человека»).

Написанная в пору работы над романом статья «Питомник нового человека» своеобразно резюмирует революционные идеи и планетарные мечтания молодых «строителей страны» об «интеллектуальной революции», мировой «коммунистической революции», призванной «перешить» «неуклюжую Вселенную», о борьбе с природой и буржуазной культурой, о новом, «более высоком типе человека» и «новой истории» - радикальном преобразовании жизни России, природы, самого мироздания и человека. Как и ранние статьи, «Питомник нового человека» представляет образец мифотворчества и пролетарской философии, строй мысли которых отличают атмосфера проективности и экспериментаторства ${ }^{12}$.

Перефразируя одно из положений представленного плана будущего романа, можно сказать, что действительно, «вещи», о которых Платонову

11 См.: «Летопись жизни и творчества А. Платонова 1899-1926 гг.» (Антонова 2016: 309-368; Ласунский 2007: 61-173).

12 О прямых перекличках положений статьи с высказываниями героев Строителей страны см. примеч. к статье (Платонов 2016: 794-796); подробно о связях романа с ранней публицистикой также см.: Вьюгин 2004: 192-221; Яблоков 2001: 102-187. 
предстояло писать роман, ему были «хорошо и опытно знакомы»; статьи, рассказы, стихи начала 1920-х гг. стали своеобразной записной книжкой уникальных материалов к первому роману писателя. Однако путь осуществления замысла о почти «фантастическом мире» оказался не таким простым, как это виделось летом 1927 г.

В работе над романом будут малые и большие остановки, связанные не только с уточнением, но и с радикальным изменением сюжета, системы образов и формул главных героев. История романа Чевенгур начиналась с текста, название которого Строители страны явно корреспондирует с планом романа в заявке Зреющая звезда. Первые главы выполнены в форме рассказа от первого лица. Этот тип повествования в теории литературы известен как «Я - форма», «Ich-Erzahlung». Для этой формы повествования характерны презентация фигуры героя-рассказчика, подчеркнутый автобиографизм, пространные философские и психологические комментарии, резкое увеличение количества авторских отступлений от основной событийной канвы. Все эти признаки обнаруживаются в архитектонике первых двух глав Строителей страны, где выбрана форма рассказа от первого лица, а сам рассказчик, как и заложено в этой традиции повествования, является одним из персонажей описываемых событий. Платоновский рассказчик не простой участник событий 1919 г. в Новохоперске, он журналист (автобиографическая деталь в мотивации новохоперского сюжета) и «сочинитель», работающий над произведением - «сочинением о сне и целомудрии, как строителях будущего человека» (конец 2-й главы), отсылающем к рассказам Платонова начала 1920-х гг. С 3-й главы Строителей страны эта фигура рассказчика исчезает, а ее биографические реалии передаются некоему Дванову, о котором во 2-й главе рассказывает Геннадий.

К лету 1927 г. относится написанная на основании собственных писем из Тамбова неоконченная повесть о любви в письмах «Однажды любившие». След этой повествовательной формы присутствует и в Строителях cmpaнbl, что нашло отражение в письмах героев к Софье Александровне с признанием в любви. Источником романного любовного эпистолярия послужили письма Платонова к Марии Александровне 1921 г., а в представленном любовном треугольнике Строителей страны нашла отражение история встречи Платонова и его воронежских друзей (Г. Малюченко и В. Келлера) с юной Марией Кашинцевой, будущей женой писателя. Превращение письма в текст потребовало минимальной правки, и письма Платонова к Марии Александровне превратились в письма Дванова к Софье Александровне ${ }^{13}$.

До Строителей страны любовный лирический сюжет оформляется у Платонова в стихах 1926-1927 г., в фантастическом «Эфирном тракте» (1926-1927) и в исторических «Епифанских шлюзах» (1927), но в обеих по-

13 Подробно см.: (Корниенко 2009: 377-390; Корниенко 2013). 
вестях он не является сюжетообразующим. «Сокровенный человек», а затем и «Ямская слобода» и вовсе обходятся без любовного сюжета. В Строителях страны любовная коллизия сразу занимает наряду с современным сюжетом центральное место, как и в других уже написанных романах о революции (Хождение по мукам А. Толстого, Города и годы и Братья К. Федина, Белая гвардия М. Булгакова, Барсуки и Вор Л. Леонова). Отказавшись с 3-й главы от фигуры рассказчика «Ich-Erzahlung», Платонов сохраняет центральность любовного сюжета (влюбленность трех друзей Гратова, Геннадия и Дванова в Софью Александровну Крашенину), что свидетельствует о том, что Платонов в 1927 г. после фантастической («Эфирный тракт»), исторической («Епифанские шлюзы»), современной («Сокровенной человек») повести осваивает новый (для него, как прозаика) тип повествования. Он не раз затем будет возвращаться к опыту (а может быть, и к рукописи) Строителей страны как к романному типу повествования (Технический роман, Счастливая Москва) и вновь от него отказываться (незавершенность работы над указанными текстами).

Автограф Строителей страны демонстрирует напряженный поиск формулы главной лирической героини. Платонов наделял героиню разными, порой прямо противоположными ролями. Софья Александровна ведет себя то как мудрая епифанская баба, то как вечная Беатриче, то как роковая Незнакомка, то как комсомолка Валя из романа Олеши (Зависть, 1927), то как Наталья Тарпова из одноименного романа С. Семенова (Наталья Tарпова, 1927). В «Строителях страны» Софье Александровне принадлежит особое место, она - лирический центр романа. Именно ей поручалось развязка любовной коллизии. Трех до болезненности влюбленных в Крашенину молодых людей (Дванова, Гратова и Геннадия) из сознания и жизни героини вытеснила фигура Копенкина, который и становится главной идеей ее жизни. Платоническая любовь к «дальнему» Копенкину определит отъезд Софьи Александровны из деревни и последующие этапы жизни героини повести: возвращение в губернский город; вступление в комсомол, учеба в губсовпартшколе, общественная работа. Последний раз Софья Александровна появляется в Строителях страны перед эпизодом партийного собрания - ее встреча с Двановым, вернувшимся в изменившийся с введением нэпа губернский город. (В свернутом виде сюжет любви Софьи Александровны к Копенкину предстанет в формуле организующей идеи героини романа Счастливая Москва Москвы Честновой, которая всех влюбленных в нее героев испытывает похожестью на человека с факелом, которого она видела в дни революции.)

К концу лета «первая треть» романа была написана, и представлена для обсуждения редактору Платонова Г. З. Литвину-Молотову. Дошедшее до нас письмо Литвина-Молотова Платонову о «Строителях страны» первый значительный опыт анализа основных героев первой части будущего романа - Геннадия, Дванова, Гратова, Мрачинского, Копенкина, Софьи и комплекса идей, транслируемых ими. Редактор внимательно вчи- 
тывается в платоновский текст, в диалоги героев, размышляет над впечатлениями, которые рождают у него как читателя сюжеты путешествия Дванова по разоренной Гражданской войной губернии, пытается сформулировать основную идею и пафос нового платоновского опыта в осмыслении революционной России:

«...глупые поиски, бредовые мысли, смешные (зло!) требования к сроку вырастить социализм, чтобы он пер прямо из травы»;

«...будничное революционное дело выставлено как попытка в срок построить социализм, и с такими комментариями от автора и от лица действующих героев, что в результате их создается лишь одно впечатление: люди беспомощно барахтаются в несбыточных идеях, мечтаниях и делах, в то время, когда надо бороться за человеческий образ жизни, что идея построения социализма - больная идея, что где-где, а в России социализм никогда не будет построен, ибо в такой отсталой стране и думать его построить его нель3я, — тому порукой примеры повести» (Архив А. П. Платонова 2019: 638).

Эти оценки позволяют редактору так резюмировать политический смысл произведения Платонова: «Впечатление таково, что будто бы автор задался целью в художественных образах и картинах показать несостоятельность идеи возможности построения социализма в одной стране. И это на другой день после осуждения партией оппозиции, выставившей это положение!» (Там же).

Смысл данного заключения, которое звучит серьезным политическим обвинением, обнажает и отражает контекст, в котором оно делается. Эпоха партийных дискуссий вокруг заявлений Л. Троцкого и возглавляемой им «левой» оппозиции (начало дискуссии - 1923 г.) закончилась в ходе подготовки празднования 10-й годовщины Октябрьской революции. Дискуссий на тему построения социализма в СССР больше не будет, а шло фронтальное осуждение «оппозиционеров-раскольников»: октябрьский объединенный пленум ЦК и ЦКК исключил Троцкого и Зиновьева из ЦК ВКП(б); 15 ноября все центральные газеты напечатали постановление ЦКК и ЦК ВКП(б) об исключении Троцкого и Зиновьева из ВКП(б) и т. п.

Это будет первая большая остановка в работе над романом, когда произойдет радикальное исправление замысла романа и всей системы героев. Переписывая финальную сцену Строителей страны (партийное собрание о введении нэпа), Платонов меняет формулу Саши Дванова (делает его сиротой), полностью отказывается от любовно-лирического сюжета, превращает Софью Александровну в сироту Соню, убирает из романа друзей Дванова. Во время этой остановки написан своеобразный пролог романа, которым экспозиция отодвигается к началу века и задается главная новая тема романа — крестьянского отхода (названия этой части романа — «Преходящие годы», «Путешествие с пустым сердцем», «Происхождение мастера»). В новой редакции партийного собрания появляется фигура Чепурного, который рассказывает Дванову о фантастическом городе Чевенгур, в котором уже построен коммунизм. Так начинается путь Дванова в город 
Чевенгур, построенный в 1861 году (дата сохранилась в сокращенном фрагменте текста об истории города) первым большим потоком отходников губернии и уничтоженный их же потомками. Погруженная в романе в большой литературный и философский контекст (А. Пушкин, Ф. Достоевский, Г. Успенский, И. Бунин, А. Чехов, М. Горький, С. Есенин, О. Шпенглер) тема крестьянского отхода фактически готовит пространство будущего Котлована (1930), где будет представлена «диалектика событий» второй большевистской революции с ее радикальным решением главного социального и политического вопроса русской истории - крестьянского вопроса.

Выявленные в настоящее время материалы к истории создания Платоновым шести романов отличают социальная заостренность их тематики, включенность «идеи романа» в актуальный для времени их написания политический контекст, а также сохраняют мощную биографическую основу, связанную с воронежским периодом жизни и творчества писателя. Биографизм проявляет себя не только в реалиях воронежского периода жизни и деятельности Платонова. Используя определение М. Бахтина, можно говорить, что Платонов «прототипом образа идеи» в романе делает собственное мировоззрение, тот круг идей, что связан прежде всего и главным образом с революцией 1917 г.14

Каждый из романов является своеобразным организующим центром разных периодов творчества Платонова 1920-1930-х гг. В рамках периода главная идея романа разрабатывается в разных формах (повесть, рассказ, драма, киносценарий, статья). Причем, пространство работы над новым романом всегда задавало ситуацию возвращения к сюжетам прежнего периода-цикла, их новую интерпретацию в контексте обозначенной новой «идеи романа». Отсюда постоянное возвращение на новом этапе творчества и истории к первому роману (Чевенгур), его проблематике, сюжетам, мотивам, формулам героев.

\section{ЛИТЕРАТУРА}

Антонова Елена. Воронежский период жизни и творчества А. П. Платонова: биография, текстология, поэтика. Москва: ИМЛИ РАН, 2016.

Архив А. П. Платонова. Кн. 1. Отв. ред. Корниенко Наталья. Москва: ИМЛИ РАН, 2009.

Архив А. П. Платонова. Кн. 2: Описание рукописи романа «Чевенгур». Динамическая транскрипция. Отв. ред. Корниенко Наталья. Подг. текста Е. В. Антонова, Н. В. Корниенко, Е. А. Папкова. Москва: ИМЛИ РАН, 2019.

Бахтин Михаил. Собрание сочинений: В 7 т. Т. 5. Москва: Русские словари, 1996.

14 См. записи М. М. Бахтина о жанре романа в русской и европейской литературе XX в.: «Превращение собственного мировоззрения в предмет художественного видения, т. е. в прототип образа идеи» (Бахтин 1996: 375). 
«Великий план электрификации СССР. На Всесоюзной конференции по электрификации СССР». Известия 8.05.1932: 2.

Вьюгин Валерий. Андрей Платонов: поэтика загадки (Очерк становления и эволюиии стиля). Санкт-Петербург: РХГИ, 2004.

Климовецкий Я. «Важнейшие вопросы эксплоатации электростанций». Правда 21.05.1932: 2.

Корниенко Наталья. «“Заметки” Андрея Платонова (Комментарий к истории невышедших книг А. Платонова 1939 года)». Русская литература 3 (1990): 179-192.

Корниенко Наталья. «От “Родины электричества" к “Техническому роману”, и обратно. Метаморфозы текста Платонова 1930-х гг.». «Страна философов» Андрея Платонова: проблемы творчества. Вып. 4. Юбилейный. Москва: ИМЛИ РАН, «Наследие», 2000: $885-936$.

Корниенко Наталья. «Между Москвой и Ленинградом: О датировке и авантексте романа “Чевенгур"». «Страна философов» Андрея Платонова: проблемы творчества. Вып. 6. Москва: ИМЛИ РАН, 2005: 624-678.

Корниенко Наталья. «“Письма о горе и любви”: Письмо и текст». Архив А. П. Платонова. Кн. 1. Москва: ИМЛИ РАН, 2009: 377-394.

Корниенко Наталья. «Андрей Платонов по его письмам». Платонов Андрей. «...я прожил жизнь»: Письма. 1920-1950 г2. Сост., вступ. статья, коммент. Н. В. Корниенко и др. Москва: Астрель, 2013: 7-71.

Лангерак Томас. Андрей Платонов. Материаль для биографии 1899-1929 г2. Амстердам: Издательство «Пегасус», 1995.

Ласунский Олег. Житель родного города. Воронежские годы Андрея Платонова. Воронеж: Центр духовного возрождения Черноземного края, 2007.

Платонов Андрей. Записные книжки. Материалы к биографии. Публ. М. А. Платоновой. Сост., подг. текста, предисл. и примеч. Н. В. Корниенко. Москва: Наследие, 2000.

Платонов Андрей. «Родина электричества». Публ. М. А. Платоновой. Подг. текста Н. В. Корниенко. «Страна философов» Андрея Платонова: проблемы творчества. Вып. 4. Юбилейный. Москва: ИМЛИ РАН, «Наследие», 2000: 745-759.

Платонов Андрей. Сочинения. Т. 2. 1926-1927. Повести. Рассказы. Сценарии. Статьи. Гл. ред. Корниенко Наталья. Москва: ИМЛИ РАН, 2016.

Платонов Андрей. Сочинения. Т. 3. Роман «Чевенгур». Гл. ред. Корниенко Наталья. Москва: ИМЛИ РАН, 2021.

Платонов Андрей. «Счастливая Москва» Публикация М. А. Платоновой. Подг. текста и коммент. Н. В. Корниенко. Послесловие С. Залыгина. Новый мир 9 (1991): 9-76.

Платонов Андрей. Технический роман. Предисловие, составление, публикация В. Шенталинского. Москва: Библиотека «Огонек», 1991.

Платонов Андрей. «Технический роман». Публ. В. Гончарова и Н. Корниенко. «Страна философов» Андрея Платонова: проблемы творчества. Вып. 4. Юбилейный. Москва: ИМЛИ РАН, «Наследие», 2000: 885-936.

Платонов Андрей. «Хлеб и чтение». Платонов Андрей. Собрание. Эфирный тракт. Ред. Малыгина Нина. Подг. Н. В. Корниенко, коммент. И. И. Матвеевой. Москва: Время, 2009.

Платонов Андрей. «...я прожил жизнь»: Письма. 1920-1950 г2. Сост., вступ. статья, коммент. Н. В. Корниенко и др. Москва: Астрель, 2013.

«Повесть А. Платонова “Строители страны”. К реконструкции произведения» Публ., вступит. ст. и коммент. В. Ю. Вьюгина). Из творческого наследия русских писателей ХХ века. М. Шолохов. А. Платонов. Л. Леонов. Санкт-Петербург: Наука, 1995: 309-390.

«Серапионовы братья» в зеркалах переписки. Вступит. ст., сост., коммент. Е. Леминга. Москва: Аграф, 2004.

Сталин Иосиф. «О задачах хозяйственников». Сталин Иосиф. Сочинения. Т. 13. Москва: Государственное издательство политической литературы, 1951: 29-42.

Толстой Алексей. «О новой литературе». Накануне. Литературное приложение 7 (62) (1922): 5-6.

«Уничтожим засуху в Заволжье». Известия 24.05.1932: 1.

Яблоков Евгений. На берегу неба: Роман Андрея Платонова «Чевенгур». Санкт-Петербург: «Дмитрий Булавин», 2001. 


\section{REFERENCES}

Antonova Elena. Voronezhskij period zhizni i tvorchestva A. P. Platonova: biografiya, tekstologiya, poetika. Moskva: IMLI RAN, 2016.

Arhiv A. P. Platonova. Kn. 1. Otv. red. Kornienko Natal'ya. Moskva: IMLI RAN, 2009.

Arhiv A. P. Platonova. Kn. 2: Opisanie rukopisi romana «CHevengur». Dinamicheskaya transkripciya. Otv. red. Kornienko Natal'ya. Podg/ teksta E. V. Antonova, N. V. Kornienko, E. A. Papkova. Moskva: IMLI RAN, 2019.

Bahtin Mihail. Sobranie sochinenij: V 7 t. T. 5. Moskva: Russkie slovari, 1996.

«Velikij plan elektrifikacii SSSR. Na Vsesoyuznoj konferencii po elektrifikacii SSSR». Izvestiya 8.05.1932: 2 .

V'yugin Valerij. Andrej Platonov: poetika zagadki (Ocherk stanovleniya i evolyucii stilya). SanktPeterburg: RHGI, 2004.

Klimoveckij Ya. «Vazhnejshie voprosy eksploatacii elektrostancij». Pravda 21.05.1932: 2.

Kornienko Natal'ya. «"Zametki” Andreya Platonova (Kommentarij k istorii nevyshedshih knig A. Platonova 1939 goda)». Russkaya literatura 3 (1990): 179-192.

Kornienko Natal'ya. "Ot "Rodiny elektrichestva" k "Tekhnicheskomu romanu”, i obratno. Metamorfozy teksta Platonova 1930-h gg.». «Strana filosofov» Andreya Platonova: problemy tvorchestva. Vyp. 4. YUbilejnyj. Moskva: IMLI RAN, «Nasledie», 2000: 885-936.

Kornienko Natal'ya. «Mezhdu Moskvoj i Leningradom: O datirovke i avantekste romana "Chevengur"». «Strana filosofov» Andreya Platonova: problemy tvorchestva. Vyp. 6. Moskva: IMLI RAN, 2005: 624-678.

Kornienko Natal'ya. «"Pis'ma o gore i lyubvi”: Pis'mo i tekst». Arhiv A. P. Platonova. Kn. 1. Moskva: IMLI RAN, 2009: 377-394.

Kornienko Natal'ya. «Andrej Platonov po ego pis'mam». Platonov Andrej. «...ya prozhil zhizn'»: Pis'ma. 1920-1950 gg. Sost., vstup. stat'ya, komment. N. V. Kornienko i dr. Moskva: Astrel', 2013: 7-71.

Langerak Tomas. Andrej Platonov. Materialy dlya biografii 1899-1929 gg. Amsterdam: Izdatel'stvo «Pegasus», 1995.

Lasunskij Oleg. Zhitel' rodnogo goroda. Voronezhskie gody Andreya Platonova. Voronezh: Centr duhovnogo vozrozhdeniya CHernozemnogo kraya, 2007.

Platonov Andrej. Zapisnye knizhki. Materialy k biografii. Publ. M. A. Platonovoj. Sost., podg. teksta, predisl. i primech. N. V. Kornienko. Moskva: Nasledie, 2000.

Platonov Andrej. «Rodina elektrichestva». Publ. M. A. Platonovoj. Podgotovka teksta N. V. Kornienko. «Strana filosofov» Andreya Platonova: problemy tvorchestva. Vyp. 4. YUbilejnyj. Moskva: IMLI RAN, «Nasledie», 2000: 745-759.

Platonov Andrej. Sochineniya. T. 2. 1926-1927. Povesti. Rasskazy. Scenarii. Stat'i. Gl. red. Kornienko Natal'ya. Moskva: IMLI RAN, 2016.

Platonov Andrej. Sochineniya. T. 3. Roman «CHevengur». Gl. red. Kornienko Natal'ya. Moskva: IMLI RAN, 2021.

Platonov Andrej. «Schastlivaya Moskva» Publikaciya M. A. Platonovoj. Podg. teksta i komment. N. V. Kornienko. Poslesl. S. Zalygina. Novyj mir 9 (1991): 9-76.

Platonov Andrej. Tekhnicheskij roman. Predisl., sostavl., publ. V. Shentalinskogo. Moskva: Biblioteka «Ogonek», 1991.

Platonov Andrej. «Tekhnicheskij roman». Publ. V. Goncharova i N. Kornienko. «Strana filosofov» Andreya Platonova: problemy tvorchestva. Vyp. 4. Yubilejnyj. Moskva: IMLI RAN, «Nasledie», 2000: 885-936.

Platonov Andrej. «Hleb i chtenie». Platonov Andrej. Sobranie. Efirnyj trakt. Red. Malygina Nina. Podg. teksta N. V. Kornienko, komment. I. I. Matveevoj. Moskva: Vremya, 2009.

Platonov Andrej. «...ya prozhil zhizn'»: Pis'ma. 1920-1950 gg. Sost., vstup. stat'ya, komment. N. V. Kornienko i dr. Moskva: Astrel', 2013.

«Povest' A. Platonova "Stroiteli strany". K rekonstrukcii proizvedeniya» Publ., vstupit. st. i komment. V. Yu. V'yugina). Iz tvorcheskogo naslediya russkih pisatelej XX veka. M. Sholohov. A. Platonov. L. Leonov. Sankt-Peterburg: Nauka, 1995: 309-390.

«Serapionovy brat'ya» v zerkalah perepiski. Vstupit. st., sost., komment. E. Leminga. Moskva: Agraf, 2004. 


\section{2}

Stalin Iosif. «O zadachah hozyajstvennikov». Stalin Iosif. Sochineniya. T. 13. Moskva: Gosudarstvennoe izdatel'stvo politicheskoj literatury, 1951: 29-42.

Tolstoj Aleksej. «O novoj literature». Nakanune. Literaturnoe prilozhenie 7(62) (1922): 5-6.

«Unichtozhim zasuhu v Zavolzh'e». Izvestiya 24.05.1932: 1.

Yablokov Evgenij. Na beregu neba: Roman Andreya Platonova "Chevengur». Sankt-Peterburg: «Dmitrij Bulavin», 2001.

Наталија Корнијенко

\section{„СОЦИЈАЛНИ РОМАН“ АНДРЕЈА ПЛАТОНОВА: КОНТЕКСТ СТВАРАЛАШТВА И ЕПОХЕ}

Резиме

Чланак је посвећен проблематици романескне уметности Андреја Платонова у контексту пишчевог стваралаштва и књижевне епохе 1920-их и 1930-их година, када роман постаје водећи прозни жанр у стваралаштву прозаичара како у совјетској Русији, тако и у емиграцији. Анализира се историјат стварања кључног пишчевог романа - романа Чевенгур (1927-1929), као и историјат незавршених (Технички роман, Срећна Москва) и ненаписаних романа (роман с радним називом Стратилат и Путовање из Лењинграда у Москву).

Кључне речи: Платонов, револуција, контекст, биографија, роман, редакције романа, писма, бележнице. 